\title{
Reflexões sobre pragmática e letramento jurídico a partir de um caso de vídeos no youtube desrespeitando cultos religiosos afro-brasileiros
}

\author{
Reflections about pragmatics and legal literacy from a case \\ of Youtube videos disrespecting afro-brazilian religious cults
}

Mestre e doutorando em Estudos LinguísAdvogado e professor de portuguêsaná.
RESUMO: Considerando que a Pragmática é o ramo da Linguística que prioriza o estudo dos princípios que orientam os processos de comunicação humana, levando em consideração os contextos em que os interactantes estão inseridos, e que sua vertente cognitivo-inferencial postula que a compreensão do significado de um enunciado (seja oral ou escrito) leva em conta as circunstâncias mentais e sociais de quem o produziu, neste trabalho utilizaremos como referencial teórico alguns conceitos dessa vertente que foram introduzidos pela Teoria da Relevância de Sperber e Wilson (1995), tal como a definição de "contexto" como um constructo psicológico dinâmico de suposições sobre o mundo. Considerando também que o estudo de casos é uma metodologia de pesquisa consolidada e adequada para problematizar situações concretas, nos apropriaremos de um episódio submetido à apreciação do Poder Judiciário brasileiro. Nesse episódio, pretendeu-se a exclusão da internet de vídeos discriminatórios aos praticantes e às práticas sociais religiosas de matriz afro-brasileira. 0 objetivo deste estudo é refletir sobre a importância da introdução dos estudos da Pragmática, especialmente de viés cognitivo-inferencial, no processo de letramento dos profissionais do Direito.

PALAVRAS-CHAVE: Pragmática; Teoria da relevância; Letramento jurídico; Práticas sociais.

ABSTRACT: Assuming that Pragmatics is the area of linguistics that prioritizes the study of the principles that guide human communication processes considering the contexts in which interactions are placed, and that its cognitive-inferential aspects posits that the understanding of the meaning of a statement (whether oral or written) considers the mental and the social circumstances of those who produced it, this paper will use as theoretical concepts some aspects introduced by Sperber and Wilson in their Relevance Theory (1995), such as the definition of "context" as a dynamic psychological construct of assumptions about the world. Considering also that the case study is a consolidated and adequate research methodology to discuss specific situations, we will analyze an episode submitted to a Brazilian Court. In this situation, the intention was to exclude from the internet videos that were discriminatory to practitioners and social practices of African-Brazilian religions, in order to discuss the importance of the introduction of Pragmatics studies, especially of cognitive-inferential trends, in the literacy process of the legal professionals.

KEYwORDS: Pragmatics; Relevance theory; Legal literacy; Social practices. 


\section{Introdução}

To ano de 2014, repercutiu na imprensa brasileira a ocorrência de um fato que deixou perplexa grande parte da população de nosso país. Tratava-se do caso de uma ação judicial na qual o Ministério Público Federal ${ }^{1}$ pleiteou que o Poder Judiciário determinasse à conhecidíssima empresa de mídias eletrônicas Google que retirasse da internet - mais especificamente dos sites sob sua responsabilidade, tais como o próprio site homônimo de buscas e pesquisas, bem como do repositório de vídeos Youtube - alguns vídeos específicos, que se encontravam acessíveis nesses locais, em canais com postagens que teriam sido feitas por entidades religiosas de orientação cristã denominadas "evangélicas".

O representante do MPF justificou seu pedido alegando que os mencionados vídeos conteriam críticas, comentários depreciativos e ofensas tanto à prática quanto aos praticantes de cultos de denominações religiosas de orientação afro-brasileira (notadamente, candomblé e umbanda), portanto, contrários a alguns direitos fundamentais elencados em nossa Constituição Federal. O conteúdo desses vídeos ofende as liberdades de opinião, de reunião e de religião de qualquer cidadão brasileiro seguidor das crenças de matriz africana ali citadas.

Nessa ação, requeria-se ainda o deferimento de liminar para a imediata exclusão de tais vídeos da internet, mesmo que em caráter provisório, até que houvesse uma sentença final, evitando-se, assim, maiores constrangimentos e o fomento ao preconceito contra a parcela da população nacional que segue e pratica os preceitos das religiões ali atacadas.

Até aquele momento, a discussão judicial estava focada em mais um caso de intolerância, no qual uma corrente religiosa fazia ataques às práticas de

\section{${ }^{1}$ Doravante MPF}

outra, e o MPF realizava seu papel de fiscalizar o cumprimento dos preceitos constitucionais que visam garantir a harmonia e a paz social.

Contudo, a celeuma que repercutiu na mídia se instaurou depois que o magistrado que estava analisando este caso entendeu que não haveria a necessidade urgente e imediata de se retirar tais vídeos da internet porque, a seu ver, não existiam evidências fortes o suficiente de que tais conteúdos pudessem colocar em risco esse tipo de "prática cultural" religiosa, uma vez que essa "prática cultural" já está "profundamente enraizada na cultura coletiva brasileira". Ou seja, como veremos logo na sequência, no entendimento do juiz, candomblé e umbanda não são religiões, mas sim "práticas culturais" (RIO DE JANEIRO, 17ạ Vara Federal, Ação Civil Pública 2014.51.01.004747-2). Ao justificar sua decisão que negou o pedido de liminar para que o Google fizesse a retirada imediata desses vídeos de seus sites, o magistrado desenvolveu seu raciocínio no seguinte sentido:

No caso, ambas manifestações de religiosidade não contêm os traços necessários de uma religião a saber, um texto base (corão, bíblia etc) ausência de estrutura hierárquica e ausência de um Deus a ser venerado.

(...)

As manifestações religiosas afro-brasileiras não se constituem em religiões, muito menos os vídeos contidos no Google refletem um sistema de crença - são de mau gosto, mas são manifestações de livre expressão de opinião. Quanto ao aspecto do direito fundamental de reunião, os vídeos bem como os cultos afro-brasileiros, não compõem uma vedação à continuidade da existência de reuniões de macumba, umbanda, candomblé ou quimbanda. Não há nos autos prova de que tais "cultos afro-brasileiros" - expressão que será desenvolvida no mérito - estejam sendo efetivamente turbados pelos vídeos inseridos no Google. (RIO DE JANEIRO, 17a Vara Federal, Ação Civil Pública 2014.51.01.004747-2)

Após tomar conhecimento do teor desta decisão, o MPF argumentou que o objeto do pedido ia além do que o magistrado apontara na sentença: tentava-se coibir a ofensa às liberdades de opinião, reunião e religião 
dos praticantes de candomblé e umbanda, e, o Procurador da República tentou ainda demonstrar nas premissas do seu pedido inicial que a simples permanência desses vídeos acessíveis pela internet cria a possibilidade de os praticantes de cultos afro-brasileiros serem alvo de intolerância. Os praticantes inclusive correriam o risco de sofrerem algum tipo de violência somente por professarem uma fé que utiliza ritos diversos daqueles utilizados nas igrejas cristãs, notadamente os da autora das afrontas, além de a incitação à intolerância e à discriminação ferirem a Lei Maior do nosso país.

Divulgando a notícia sobre esta decisão judicial, a revista Exame ${ }^{2}$ publicou, em sua versão digital, entrevistas com algumas das partes diretamente envolvidas no caso - o representante do MPF, o presidente da Associação Nacional de Mídia Afro - autor das denúncias sobre a existência de tais vídeos na internet - bem como um representante de uma das religiões atacadas - as quais declararam ao periódico:

O ordenamento jurídico brasileiro estabelece que as relações sociais devem primar pela solidariedade, liberdade de crença e de religião, pelo respeito mútuo, pela consagração da pluralidade e da diversidade. A liberdade de expressar crença religiosa ou convicção não serve de escudo para acobertar violações aos direitos humanos, atacando ou ofendendo pessoa ou grupo de pessoas. (Jaime Mitropoulos, Procurador da República)

Essa intolerância tomou uma proporção absurda. A gente não pode conviver com isso com naturalidade. Hoje são (atacadas) as religiões africanas, amanhã podem ser os judeus, os católicos, os evangélicos. (Márcio Righetti, presidente da Associação Nacional de Mídia Afro)

Realmente não há uma hierarquia nem um código canônico que oriente as religiões de origem africana, mas isso não faz com que elas não sejam religiões. Além de serem religiões, o candomblé e a umbanda são filosofias de vida e manifestações culturais enraizadas no Brasil. (Manoel Alves de Souza, presidente da Federação Brasileira de Umbanda)

2 Disponível em: <http://exame.abril.com.br/brasil/noticias/para-juiz-candomble-e-umbanda-nao-saoreligioes>. Acesso em: 15 ago. 2014.
A discussão sobre a discriminação aos cultos religiosos afro-brasileiros descambou, então, para outro polo: profissionais com formação jurídica, teoricamente habilitados para interpretar leis e solucionar conflitos sociais como o magistrado responsável por julgar este caso, teriam conhecimento técnico e competência para dizer se essa ou aquela manifestação cultural são, efetivamente, uma religião ou não?

A reflexão a que nos propomos aqui não abrange a competência jurisdicional do magistrado - ou seja, aquela conferida pela lei que lhe dá poder para apresentar uma decisão e ver essa decisão acatada e cumprida pelos envolvidos. Gostaríamos, sim, de refletir sobre possíveis fatores que permeiam uma interpretação, ou seja, tentar demonstrar com suporte no referencial teórico apresentado pela pragmática cognitivo-inferencial, porque se opta por um ou outro caminho e, a partir daí, sugerir possíveis contribuições.

\section{Reflexões sobre a decisão judicial no episódio dos vídeos}

\subsection{Letramento}

Pois bem, os profissionais que trabalham em busca de soluções para os conflitos sociais, notadamente os operadores do Direito, precisam de uma sólida formação educacional, cultural, ética e moral, além de plena capacidade cognitivo-inferencial para articular todas essas competências.

Como um dos nossos enfoques será a questão do letramento jurídico, vamos nos ater aos aspectos da formação educacional que habilita um cidadão a tornar-se bacharel em Direito e ter a possibilidade concreta de um dia ser alçado à condição de magistrado, passando a determinar, grosso modo de dizer, quem está certo ou quem está errado nos conflitos que lhe são trazidos para julgar. 
No mundo globalizado contemporâneo, onde as relações deixaram de ser somente pessoais e passaram também para uma instância virtual, requerse competência para o uso de várias habilidades pessoais e interpessoais, a fim de que se possa, pelo menos, transitar com o mínimo de mobilidade nos diversos círculos sociais que frequentamos, seja por escolha pessoal, seja por imposições econômicas, familiares, profissionais etc. Hoje já está mais assentada a ideia de que a alfabetização pura e simples, vista como prática de mero aprendizado de decodificação e codificação, isoladamente, não leva o indivíduo muito longe em matéria de desenvolvimento pessoal.

No caso dos magistrados, são exigidas, dentre outras competências, habilidades no manuseio de todo referencial doutrinário, jurisprudencial e legal em vigor no momento em que está judicando, a fim de interpretá-lo adequadamente e o bom manejo de habilidades comunicativas com as partes que estão envolvidas na relação jurídica-processual - o autor, o réu, seus advogados, o Ministério Público, as testemunhas, os peritos etc. Vamos focar neste último aspecto.

A relação que se estabelece entre o magistrado e as partes de um processo é uma relação comunicativa bastante peculiar. Primeiro, porque é uma relação que, por tradição, se estabelece inicialmente através da escrita e não da fala. $\mathrm{O}$ advogado do autor expõe por escrito aquilo que o seu cliente deseja obter do judiciário. Ou seja, além de esse primeiro contato ser por escrito, é também indireto, na medida em que o autor diz ao seu advogado o que quer e este profissional tem a responsabilidade de peticionar por escrito ao juiz expondo o pedido do cliente. Num segundo momento, o juiz ordena que se intime o réu para que "entre nessa conversa" e exponha suas razões a respeito do que o autor está pleiteando. Forma-se então outra cadeia indireta de comunicação na qual o réu também terá que contratar um advogado para representá-lo perante a justiça, e tal profissional fará a transposição para a escrita daquilo que seu cliente lhe transmitiu oralmente.
A questão que nos surge agora é: como esses textos escritos pelos advogados são lidos e interpretados pelo magistrado?

Para apreensão dos significados dos conteúdos dos textos legais e das alegações apresentadas pelas partes, é necessário que o magistrado utilize sua capacidade interpretativa (ou cognitivo-inferencial), a fim de identificar as intenções comunicativas de todos os envolvidos nessa interação e solucionar o conflito. Mais adiante vamos aprofundar essas colocações. Agora queremos somente apontá-las para demonstrar a influência que cremos que o letramento tem para o desempenho dessa capacidade.

Embora a definição do termo "letramento" varie conforme a abordagem teórico-ideológica utilizada, neste trabalho vamos assumi-la

como a busca de uma maior flexibilidade comunicativa, na prática, tentar justamente inserir o interlocutor em sua alteridade - modo de vida ou modo de raciocinar/agir/avaliar no cotidiano - nesse mundo homogeneizado significa também correr o risco de tornar vulnerável todo um edifício feito de leis e razões, inclusive a base de natureza ideológico-cultural, diretamente relacionada com a distribuição do poder na sociedade e na interação comunicativa. Nesse sentido, toda ação visando a esse objetivo tem uma dimensão política indiscutível, dificilmente assumida pela perspectiva informacional (pollianesca) cultivada institucionalmente. (SIGNORINI, 1995, p. 195-196)

Neste sentido, podemos remarcar que o debate sobre letramento não é simplesmente um fórum sobre como capacitar melhor as pessoas para ler, escrever e fazer operações matemáticas. Muito mais do que isso, constitui também uma discussão sobre como proporcionar condições para o desenvolvimento da autonomia pessoal e para capacitação do exercício pleno da cidadania dos membros de uma comunidade a ponto de torná-los conscientes de seu papel naquela sociedade.

Quando nos referimos a "letramento jurídico" no título deste artigo, estávamos pensando na possibilidade de elaborar paradigmas educacionais 
alternativos que pudessem proporcionar aos interessados habilidades práticas para conhecer, enfrentar, saber lidar e superar os desafios impostos pelo grupo social em que estão inseridos. Modelos alternativos que propiciassem condições de ir além da transmissão de técnicas teóricas, de simulações artificiais e de análises repetitivas de casos ultrapassados.

Ao tomarmos conhecimento deste caso em que um magistrado analisou uma acusação de discriminação religiosa e não determinou a retirada imediata da internet dos vídeos considerados ofensivos aos reclamantes sob o fundamento de que os cultos afro-brasileiros não têm seus rituais registrados em textos escritos, que não há hierarquia entre seus praticantes e que não há um "deus" específico a ser venerando, vimos a apropriação de um discurso que reflete os séculos de predominância das práticas educacionais trazidas pelos colonizadores europeus. Tais práticas supervalorizam a comunicação escrita e a hierarquização das relações sociais, e pouco se tem feito para mudar esse cenário. Com efeito, nesse mesmo discurso podemos constatar que há uma rejeição às práticas culturais fundadas na tradição da oralidade e aos modelos sociais que não se encaixam nos paradigmas tradicionais, copiados de outras sociedades não necessariamente tão heterogêneas quanto a brasileira.

Percebe-se aí quão distante o modelo de letramento que formou esse juiz está daquele proposto por Signorini na citação anterior, e quão estranha é, para ele, a realidade social vivida pela parcela de membros de sua própria comunidade que não dá importância se os rituais que praticam estão descritos em algum livro, tampouco se não veneram a um deus específico ou o fato de não haver um organograma para designar o que cada um tem que fazer durante o culto.

Essa questão da busca pela qualidade na capacitação dos futuros magistrados, com o objetivo de tornar a prestação jurisdicional mais eficiente e inclusiva é motivo de preocupação das entidades formadoras vinculadas ao judiciário, como as Escolas da Magistratura. Pesquisadora do tema, a também magistrada, professora e coordenadora de cursos para formação e preparação de magistrados, Graça Maria Borges de Freitas disserta a esse respeito citando o sociólogo Boaventura de Sousa Santos, o qual também estuda os temas relacionados à formação dos magistrados lusitanos:

Nesse contexto, Santos [...] chama a atenção para os riscos do despreparo da magistratura na sociedade atual e põe em relevo [...] a importância dos sistemas de formação e recrutamento de magistrados e a necessidade hoje, de uma magistratura "culturalmente esclarecida", isto é, com um certo "distanciamento crítico" e "prudente vigilância pessoal no exercício das suas funções", destacando, em relação à formação dos magistrados:

[...] a necessidade urgente de os dotar de conhecimentos culturais, sociológicos e econômicos que os esclareçam sobre as suas próprias opções pessoais e sobre o significado político do corpo profissional a que pertencem, com vista a possibilitar-lhes um certo distanciamento crítico e uma atitude de prudente vigilância pessoal no exercício das suas funções numa sociedade cada vez mais complexa e dinâmica. (FREITAS, 2007, p. 82)

O caso ilustrativo da Ação Civil Pública no 2014.51.01.004747-2 é mais um exemplo do efeito causado por um modelo de letramento que não consegue preparar adequadamente profissionais que têm como ofício dar conta de solucionar os conflitos do cotidiano, ainda que esses conflitos não estejam cobertos ipsis litteris pelo ordenamento jurídico.

Signorini (1995) ainda aponta potenciais problemas que decorrem das deficiências de um modelo de letramento ineficiente:

A principal consequência disso é que essas práticas escolares, também prestigiadas pela sociedade burocrática, passam a determinar os padrões discursivos reguladores do aceitável e do não-aceitável, do pertinente e do não-pertinente (relevância) na comunicação social. Da mesma forma, saber ou não manipular os meios linguísticos necessários passa a ser uma prova da capacidade individual de reflexão e de domínio do conhecimento. (SIGNORINI, 1995, p. 181) 
A esta altura o leitor estará perguntando, o que a pragmática tem a ver com tudo isso que foi exposto até agora?

Vejamos: estamos refletindo a respeito da interpretação de um magistrado a alguns artigos da Constituição que serviram de base para o pedido judicial que o MPF apresentou em juízo, interpretação essa que repercutiu negativamente não só na mídia, como em várias instâncias sociais. A partir deste episódio voltamos nossa lente de análise questionando o modelo de letramento vigente em nossa sociedade que, a nosso ver, influenciou na interpretação apresentada na decisão. Na base de tudo isso, como já apontamos anteriormente, subjaz um evento comunicativo no qual interagem o MPF, representando os ofendidos, e o próprio magistrado. É justamente aí que entra a pragmática.

\subsection{Pragmática cognitiva e Teoria da Relevância}

A comunicação humana envolve um grau de sofisticação maior do que aquele apontado no modelo teórico de código ${ }^{3}$ e que exige do ouvinte-receptor algo além da mera decodificação do que foi transmitido (ou codificado) pelo falante-emissor, sob pena de a interação não ser bem-sucedida. Tanto é assim que Sperber (1996) observa que, em determinado momento, os estudiosos dos fenômenos linguísticos sociais perceberam que era necessário fazer a distinção entre o "significado de uma sentença" e o "significado do falante" para tal sentença.

Sperber (1996) segue dissertando que uma versão aperfeiçoada do conceito informacional de comunicação (emissor-código-receptor) poderia, sim, preservar a ideia de que é necessário o conhecimento compartilhado da linguagem entre os interactantes, porém, além disso, também deveria

3 Onde há um emissor, um código e um receptor. O contexto fica margeando esses três elementos. Esse
modelo foi proposto por Shannon e Weaver em 1949 e adaptado para a comunicação humana por Jakobson em 1961 (BORDERÍA apud SANTOS, 2009). incorporar a constatação de que os seres humanos não precisam codificar ou decodificar tudo para que o processo comunicativo seja efetivamente satisfeito. Isso porque, além de "decodificar o código", nossa capacidade de inferir ou raciocinar também possibilita que apreendamos (ou impliquemos) o que nos foi transmitido através do uso de nossas habilidades cognitivas de observação dos fatores extralinguísticos, tais como as reações e expressões faciais do interlocutor, o nosso entorno físico, enfim, a percepção do "contexto".

Quanto à possibilidade de utilizarmos um evento real apresentado à apreciação do Poder Judiciário brasileiro como ponto de partida para discussão dos fenômenos sociais e linguísticos que subjazem ao episódio, Dascal (2006) leciona que qualquer espécie de fenômeno social que envolva a comunicação humana, e a manipulação de informações, possibilitaria a apropriação de instrumentos de análise linguística como ferramentas que nos permitam levar em consideração, não só o processo de comunicação em si próprio, mas também os fatos e os valores que o permeiam, e as consequências que acarretam em nosso meio social.

E no que diz respeito à análise de outros elementos que envolvem um evento comunicativo jurídico, como a interpretação de enunciados legais, o renomado jurista constitucional português Canotilho (2000), salienta que

(...) palavras e expressões do texto da norma constitucional (e de qualquer texto normativo) não têm significado autônomo, ou seja, um significado "em si", se não se tomar em conta o momento de decisão dos juristas e o carácter procedimental da concretização de normas. Daí que: (1) a decisão dos "casos" não seja uma "paráfrase" do texto da norma, pois o texto possui sempre uma dimensão comunicativa (pragmática) que é inseparável dos sujeitos utilizadores das expressões linguísticas, da sua compreensão da realidade, dos seus conhecimentos privados (neste sentido falam também as correntes hermenêuticas do efeito criador da "pré-compreensão"); (2) o texto da norma aponta para um "referente", o que quer dizer constituir o texto um sinal linguístico cujo significado aponta para um universo de realidade exterior ao texto. (CANOTILHO, 2000, p. 1219) 
Assim, estamos de acordo com tais proposições apresentadas por Sperber, Dascal e Canotilho, haja vista que sem levar em conta os fatores extralinguísticos a interpretação dos textos jurídicos e dos argumentos das partes envolvidas em um processo judicial fica muito prejudicada, ou praticamente inexistente.

Posto isso, chegamos à nossa hipótese de que a linguística, a partir da pragmática de viés cognitivo-inferencial pode auxiliar no desenvolvimento de ferramentas teóricas e metodológicas capazes de colaborar com o processo de letramento dos profissionais do direito, e não só com estes, mas também com os de outras categorias, auxiliando a suprir eventuais deficiências e aprimorando a qualidade de desempenho das suas atividades. E o referencial teórico para defender nossa premissa se assenta nos postulados apresentados por Sperber e Wilson (1995) na Teoria da Relevância4 .

Partindo das ideias deixadas por Grice (1957), de que o falante quer comunicar algo que não esteja necessariamente ligado ao significado literal das palavras ou dos enunciados que ele profere, Sperber e Wilson postulam que para interpretar um enunciado o ouvinte sabe, previamente, que numa interação o falante visa atingir um objetivo com as palavras que profere, ou seja, sempre existe alguma intenção que vai além do significado semântico explícito na estrutura sintática enunciada, mas que não é verbalizada. E justamente por ter essa consciência prévia de que se precisa elaborar o que lhe está sendo dito, levando em conta quem diz e em quais condições, tal enunciado lhe foi dirigido. Nessa perspectiva, o ouvinte não é um agente passivo na relação de interação comunicativa, na medida em que age ativamente realizando uma série de inferências, a fim de "desimplicar" a(s) intenção(ões) contida(s) no enunciado que o falante lhe endereçou.

${ }_{4}$ Doravante TR.
Ainda segundo a TR, a capacidade cognitivo-inferencial humana pressupõe que as premissas dos raciocínios que desenvolvemos são construídas a partir de informações novas processadas no conjunto de informações já existentes em nossa memória (nosso repertório de suposições, crenças, conhecimento de mundo etc.). E este processo requer habilidades inferenciais (raciocínio) para que possamos derivar conclusões adequadas.

Cabe agora ressaltar que a pragmática de base cognitiva, mencionada como suporte teórico neste artigo, constitui um modelo ostensivoinferencial de comunicação que busca descrever e explicar o processamento de informações que levam à compreensão de enunciados, através de um raciocínio lógico, mas não desconsidera que os conhecimentos de mundo variam de pessoa para pessoa e não propõe que a comunicação seja sempre bem-sucedida.

A partir disso, Benfatti e Godoy (2014) nos apontam que o desenvolvimento da pragmática tem demonstrado que a manifestação concreta da linguagem é vastamente ostensivo-inferencial, ou seja, não se define por questões vericondicionais, mas demanda a intensa negociação entre as partes envolvidas na interação. Para melhor compreensão destes apontamentos, vamos detalhar os dois conceitos acima mencionados: "inferencial" e "ostensivo".

A condição inferencial do processo comunicativo nos indica que em uma interação o ouvinte tem um papel ativo naquele ato: ele age fazendo inferências, ou seja, ele tem o objetivo de compreender e assimilar as intenções contidas nas informações que o interlocutor (falante) está transmitindo. No entanto, o ouvinte só vai despender o tempo e esforços que julgar como minimamente necessários para inferir a intenção original do falante, ou selecionar apenas o que lhe for importante interpretar.

Já quanto à condição "ostensiva" no ato comunicativo é Santos (2009) quem nos esclarece: 
Existe, contudo, na comunicação humana, um comportamento que se move na direção da "busca de mostrar algo a alguém", um comportamento que "torna manifesta uma intenção de tornar alguma coisa manifesta". Esse comportamento é, para a TR, uma ostensão. Indissociável da ostensão é o esforço de processamento, que só será feito na expectativa de alguma recompensa. Não interessa chamar a atenção de alguém para algum fenômeno se esse fenômeno não parece suficientemente relevante a essa pessoa - valer a pena prestar atenção a esse fenômeno. (...) 0 comportamento ostensivo fornece evidências dos pensamentos de uma pessoa, porque implica uma certa garantia de relevância, ou seja, os seres humanos prestam automaticamente atenção naquilo que lhes parece relevante. Qualquer outra suposição relacionada com o comportamento ostensivo será incompatível com sua confiança na garantia de relevância que ela traz. (SANTOS, 2009, p. 77-78)

É importante introduzir agora outro elemento chave para compreensão dos postulados da TR, que vai influenciar em grande medida o sucesso ou insucesso das interações comunicativas: o conceito de contexto.

Em um artigo específico sobre a definição de contexto apresentada na TR, Santos (2013) esclarece que ela não remete apenas a algo restrito ao ambiente físico do mundo real ou ao co-texto, mas engloba também todas as expectativas que se tornam acessíveis à mente durante o processamento da informação, tais como hipóteses científicas, crenças culturais, valores e saberes incorporados pelos interlocutores. Ou seja, contexto é uma construção psicológica dinâmica; um apanhado de suposições que fazemos sobre o mundo. Nesse sentido, cada nova informação (ou novo input) que nos é transmitida por nosso interlocutor gera uma representação mental que vai sendo alterada ou moldada até que apreendamos um significado ou elaboremos uma interpretação que nos deixe satisfeitos.

Os autores da TR ainda mencionam que há um princípio produtivo e econômico regendo o processo comunicativo, segundo o qual a quantidade adequada de efeitos contextuais é alcançável com o mínimo necessário de esforço cognitivo. Ou seja, a economia produtiva vale tanto para o falante - na medida em que este só precisa enunciar ao ouvinte a quantidade adequada de informações a fim de que aquele compreenda suas intenções e informações -, quanto para o ouvinte - que para interpretar só empregará o tempo e esforços que julgar minimamente necessários para depreender a intenção original do falante, ou aquela que lhe for conveniente compreender. E a mensuração do que é conveniente será variável, conforme o falante for percebendo fatores mais ou menos facilitadores que sejam ativados nos contextos internos do ouvinte.

Feitas estas colocações retomemos nosso exemplo. 0 juiz possui em sua mente um repertório de valores, informações, convicções, crenças e descrenças adquiridas ao longo de toda sua vida, incluindo-se aí aqueles transmitidos pela escola. Quando uma disputa lhe é apresentada, ele vai analisar essas novas informações trazidas pelos advogados do autor e do réu, também consultará a legislação, a jurisprudência etc. para, a partir daí, processar esse conjunto de inputs até que chegue a uma conclusão ou veredito. Para melhor visualização desse processo, elaboramos a figura abaixo:

Figura 1 - Processamento cognitivo inferencial

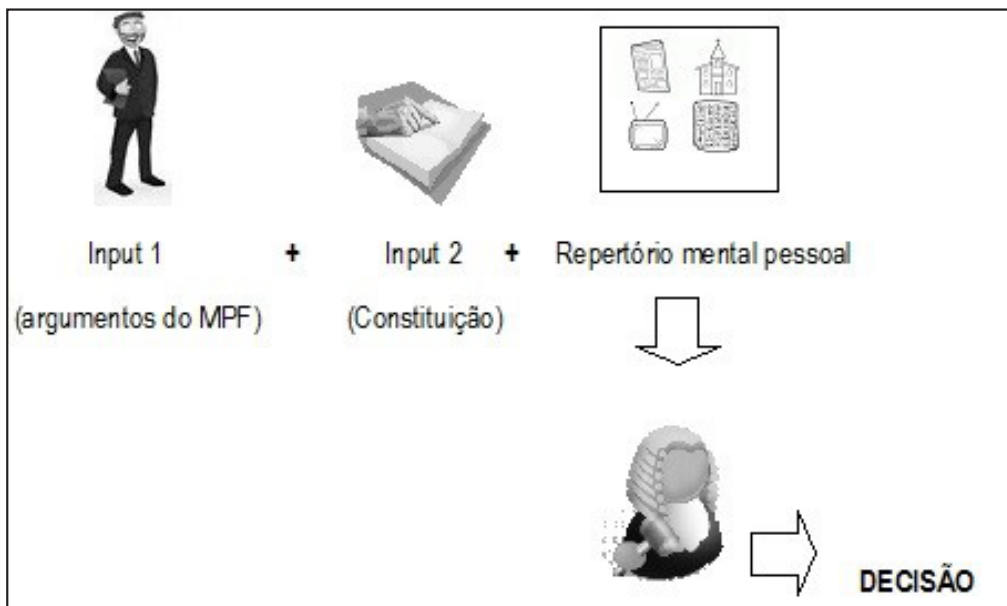


Vamos descrever o que está representando no esquema acima transpondo o caso retratado no exemplo, a fim de elaborarmos uma análise conforme os postulados da TR:

\section{Argumentos do Ministério Público Federal:}

[...] Alguns vídeos encontrados no youtube 'disseminam a intolerância e a discriminação contra as religiões de matrizes africanas'. (Processo administrativo instaurado no MPF/RJ sob no 1.30.001.000562/2014-30 apud Ação Civil Pública no 2014.51.01.004747-2)

A criteriosa análise [dos vídeos] acabou revelando que as mensagens de fato ofendem, disseminam preconceito, intolerância, discriminação, e difundem o ódio, a hostilidade, o desprezo, a violência.

$[\cdots]$

Portanto, presentes os requisitos necessários à concessão da tutela antecipada, requer o Ministério Público Federal, com esteio no art. 12 da Lei no $7.347 / 85$, o deferimento inaudita altera parte da seguinte medida de urgência: I) a retirada dos conteúdos da internet, no prazo de setenta e duas horas, cominando-se a multa de $\mathrm{R} \$ 500.000,00$ (quinhentos mil reais) por dia de descumprimento da ordem judicial, a partir do primeiro dia subsequente ao final do prazo estabelecido. (Ação Civil Pública no 2014.51.01.004747-2)

2. Constituição Federal brasileira:

Art. 5o, IV: élivre a manifestação do pensamento, sendo vedado o anonimato; Idem, VI: é inviolável a liberdade de consciência e de crença, sendo assegurado o livre exercício dos cultos religiosos e garantida, na forma da lei, a proteção aos locais de culto e a suas liturgias.

3. Repertório mental do magistrado:

No caso, ambas manifestações de religiosidade não contêm os traços necessários de uma religião a saber, um texto base (corão, bíblia etc) ausência de estrutura hierárquica e ausência de um Deus a ser venerado [...]

As manifestações religiosas afro-brasileiras não se constituem em religiões [...]. (Ação Civil Pública no 2014.51.01.004747-2)
Vemos que a partir da denúncia feita pela Associação Nacional de Mídia Afro o MPF redigiu uma petição apresentando os fatos (input 1) e requerendo providências do judiciário representado pelo magistrado. 0 texto legal (art. $5^{\circ}$ incisos IV e VI da Constituição brasileira) também foi acessado pelo juiz (input 2). Ou seja, o aparato cognitivo do magistrado recebeu dois inputs externos que lhe foram ostentados, e a partir da conjunção desses elementos podemos dizer que há o início do processamento inferencial mental.

Ao mesmo tempo, enquanto realiza o processo inferencial dos dois inputs recebidos, o magistrado vai acessar seu repertório mental interno (3), constituído pelo seu acervo pessoal de opiniões, crenças e valores que internalizou ao longo da vida - tal como a ideia preconcebida de que "as manifestações religiosas afro-brasileiras não se constituem em religiões".

O resultado dos processamentos dessas informações constitui a decisão ou o julgamento. Ou seja, a sentença nada mais é do que o subproduto das inferências que o magistrado elaborou a partir dos inputs que lhe foram ostentados conjugados com seu acervo mental próprio.

Agora vale perguntar: por que o magistrado acabou optando por negar o pedido do MPF para que fossem retirados os vídeos da internet ofensivos às religiões afro-brasileiras baseados no princípio constitucional da liberdade de culto?

Parece-nos que durante a elaboração do processo cognitivo-inferencial que o juiz desenvolveu, ao proferir sua decisão, prevaleceu o argumento de que ele já trazia internalizado em seu acervo mental de opiniões pessoais: "as manifestações religiosas afro-brasileiras não se constituem em religiões".

Sperber e Wilson (1995) nos explicam que quando estamos em uma interação comunicativa, durante o processo inferencial nossas interpretações 
decorrem do processamento que fazemos a partir de um conjunto de premissas. A mente humana trabalha buscando um equilíbrio entre o esforço gerado pelo processamento até chegar a um efeito que a satisfará, e, quando ocorrer a satisfação, ela suspenderá o processamento mental nesse ponto exato, sem a necessidade de continuar testando as outras possibilidades ad infinitum. No caso, "dadas duas propostas comunicativas concorrentes, a relevância, considerada comparativamente ${ }^{5}$, será maior quanto mais baixo o custo e quanto mais alto o benefício" (CAMPOS, 2008).

Conforme a TR, esse seria o princípio da "relevância máxima", ou seja, de todas as propostas acessíveis sobre as premissas ostentadas pelos interlocutores (MPF), mais as propostas apreendidas dos enunciados dos textos jurídicos pertinentes (artigos da Constituição Federal), cotejadas com a proposta internalizada em seu aparato mental ("as manifestações religiosas afro-brasileiras não se constituem em religiões”), o magistrado testará mentalmente essas propostas e acabará optando pela primeira que por ele for considerada a mais relevante, qual seja, aquela que gerar efeitos cognitivos suficientes para satisfazê-lo ao custo mais baixo de processamento mental. No caso do exemplo, prevaleceu a proposta preconcebida e internalizada de que "as manifestações religiosas afro-brasileiras não se constituem em religiões", portanto, o juiz considerou que “(...) não há nos autos prova de que tais 'cultos afro-brasileiros' (...) estejam sendo efetivamente turbados pelos vídeos inseridos no Google" 6 e, por isso, indeferiu o pedido de liminar feito pelo MPF.

A respeito de como os registros que mantemos na memória influenciam a mente humana trazemos as pertinentes observações do consagrado neurocientista António R. Damásio (2011):

${ }^{5}$ Deve-se ter em mente "relevância" como comparação.

6 RIO DE JANEIRO, 17ạ Vara Federal, Ação Civil Pública 2014.51.01.004747-2
Nossas memórias de certos objetos são governadas por nosso conhecimento prévio de objetos comparáveis ou de situações semelhantes. Nossas memórias são preconceituadas, no sentido estrito do termo, pela nossa história e crenças prévias. (DAMÁSIO, 2011, p. 169)

Com base nestes apontamentos, podemos perceber, após a análise deste caso que nos serve de exemplo, que a interação entre MPF/lei/juiz é permeada pelos valores adquiridos e incorporados ao acervo mental pessoal, e a tão decantada equidade do julgador é algo idealizado.

Santos (2009) complementa com apoio na TR:

Os recursos totais dos indivíduos para processamento de informações são, se não praticamente fixos, pelo menos não muito flexíveis. Assim, a eficiência cognitiva de longo prazo é construída pelo melhoramento, tanto quanto possível, do conhecimento que uma pessoa tem do mundo, dados os recursos disponíveis. (SANTOS, 2009, p. 76)

A nossa hipótese é de que os estudos da pragmática cognitiva-inferencial podem servir como instrumento capaz de auxiliar no aprimoramento do processo de letramento de categorias profissionais importantes como a magistratura, a qual, por exemplo, tem dentre suas atribuições a manutenção da paz social de uma comunidade. Diante disso, cremos que esta vertente teórica pode oferecer ideias para elaboração de um novo paradigma de letramento jurídico capaz de ajudar os futuros profissionais a ter um desenvolvimento não só racional e lógico sobre o mundo, mas também a consciência e a clareza de que suas convicções, suas crenças e seus conceitos preconcebidos podem sim interferir na análise de alguma situação e, eventualmente, vir a prejudicar os jurisdicionados.

Na medida em que se torna evidente a necessidade de se incluir nos currículos de formação jurídica disciplinas como a pragmática, talvez possamos formar uma nova geração consciente da importância do 
uso das estratégias cognitivo-inferenciais para construir sentidos, reconhecer as diferentes intenções do legislador ou das partes, das testemunhas etc.

Enfim, partir em busca de significados que emergem do mundo concreto, e enxergar a necessidade de comparar, nesse processo, repertórios mentais com a realidade social em que estamos inseridos, propicia exercitar nossa alteridade e aprender a lidar melhor com a imprevisibilidade e a instabilidade das situações da vida. Afinal, os conflitos humanos são elementos pragmáticos subjacentes à natureza humana e estão presentes em todas as situações da vida em sociedade, sendo que, em um momento ou em outro, todos vamos ter que lidar com eles, e o ideal seria estarmos minimamente preparados.

\section{2 Últimas reflexões}

Não tivemos a pretensão de, nestas páginas, apresentar um esboço de modelo de letramento que equacione as questões que levantamos. A ideia aqui foi trazermos à luz algumas reflexões sobre as implicações que as boas ou más relações entre os sujeitos e a linguagem trazem à vida de uma comunidade, um país, e sobre a necessidade de repensar o modelo de letramento jurídico focando as atuais necessidades de formação dos operadores do direito.

A busca pelo aprimoramento do letramento dos profissionais do direito, a nosso ver, passa necessariamente pela tarefa de inseri-los na alteridade dos seus interlocutores, ou seja, torná-los capazes de reconhecer que, além do que está ou não previsto em lei, há uma relação de poder interpessoal influenciada pelas premissas preconcebidas contidas nas representações que fazem parte do seu acervo mental. E porque se espera que tais profissionais sejam equânimes e verdadeiros agentes promotores da Justiça, tais representações mentais pessoais dos significados devem ser enriquecidas durante o processamento inferencial preferencialmente de forma equilibrada entre os processos linguísticos (semânticos) e os processos cognitivos (pragmáticos) trazidos nos contextos.

Sendo assim, vislumbramos que um caminho possível para o letramento eficaz dessa categoria específica de profissionais seria aquele que contemplasse a possibilidade de apresentar-lhes os conceitos da pragmática cognitiva-inferencial, a fim de dar-lhes a possibilidade de, ao se depararem com as novas situações que lhes são apresentadas, tenham capacidade para fazer um movimento de ir e vir do contexto mental (imaterial) para o contexto social (material), como um exercício dialético, já sugerido por Aristóteles.

O deslinde do caso: passados alguns dias da ampla divulgação dessa sentença polêmica o magistrado a reviu parcialmente e reconheceu, talvez por conta da enorme pressão advinda da repercussão midiática do caso, que umbanda, candomblé e outros cultos afro-brasileiros são, sim, religiões:

Em despacho publicado no início da noite desta terça-feira (20/5) pela Justiça Federal do Rio de Janeiro, o juiz da 17 - Vara de Fazenda Federal Eugênio Rosa de Araújo, voltou atrás e reviu os fundamentos da decisão na qual escreveu que 'manifestações religiosas afro-brasileiras não se constituem religião'. Ao admitir o erro, o juiz disse que 'o forte apoio dado pela mídia e pela sociedade civil, demonstra, por si só, e de forma inquestionável, a crença no culto de tais religiões'7.

7 Notícia disponível em <http://anma.org.br/juiz-recua-em-manifestacoes-sobre-religioes-africanas-masmantem-decisao/>. Acesso em: 16 ago. 2014. 


\section{Referências}

BENFATTI, Maurício F. N.; GODOY, Elena. Dos discursos de ódio como enredos ficcionais da vida real. Anais do II Workshop Internacional de Pragmática da UFPR. Curitiba: Imprensa da UFPR (no prelo).

BRASIL. Poder Judiciário. Seção Judiciária do Rio de Janeiro. 17ạ Vara Federal, Ação Civil Pública no 2014.51.01.004747-2. Disponível em: <http://procweb.jfrj.jus.br/portal/ consulta/resconsproc.asp>. Acesso em: 15 ago. 2014.

CAMPOS, Jorge da Costa. Seminário de Semântica do PPGL da PUCRS. Porto Alegre, 2008.

CANOTILHO, Joaquim José Gomes. Direito constitucional e teoria da constituição. Coimbra: Almedina, 2003.

DAMÁSIO, António R. E o cérebro criou o homem. São Paulo: Companhia das Letras, 2011.

DASCAL, Marcelo. Interpretação e compreensão. São Leopoldo: Unisinos, 2006.

FREITAS, Graça M. B. Formação de magistrados no Brasil: um modelo educativo institucional em construção após a Constituição de 1988. Rev. Trib. Reg. Trab. $3^{\text {a }}$ Reg., Belo Horizonte, v. 46, n. 76, p. 81-92, jul./dez. 2007. Disponível em: <http://www.trt3.jus. br/escola/download/revista/rev_76/Graca_Freitas.pdf>. Acesso em: 21 ago. 2014.

GRICE, H. P. Lógica e conversação. In DASCAL, Marcelo (Org.). Fundamentos Metodológicos da Linguística: Pragmática. São Paulo: Editora do autor, 1980.

REVISTA EXAME. Edição on-line de 16/05/2014. Disponível em: <http://exame.abril. com.br/brasil/noticias/para-juiz-candomble-e-umbanda-nao-sao-religioes>. Acesso em: 15 ago. 2014.

SIGNORINI, Inês. Letramento e (in)flexibilidade comunicativa. In: KLEIMAN, Angela B. (Org.). Os significados do letramento: uma nova perspectiva sobre a prática social da escrita. Campinas: Mercado das Letras, 1995.

SANTOS, Sebastião L. A interpretação da piada na perspectiva da Teoria da Relevância. Tese (Doutorado em Estudos Linguísticos) - Universidade Federal do Paraná. Curitiba, 2009.

SANTOS, Sebastião L. Contexto e contextualização: quando o significado acontece. In: Anais do XII CIEL Congresso Internacional de Estudos em Linguagem - UEPG, 2013.
SPERBER, Dan; WILSON, Deirdre. Relevance: communication \& cognition. 2. ed. Oxford: Blackwell, 1995.

SPERBER, Dan. Explaining Culture: A naturalistic approach. Oxford: Blackwell, 1996.

Recebido em 18 de dezembro de 2014.

Aceito em 18 de maio de 2015. 